\title{
Representational Structure of Vitiligo: Non-Restrictive Skin Marks
}

\author{
Emerson Araújo Do Bú*, \\ Orcid.org/0000-0003-3864-3872 \\ Maria da Penha de Lima Coutinho', 3 \\ Orcid.org/0000-0003-3961-2402 \\ ${ }^{1}$ Universidade de Lisboa, Lisboa, Portugal \\ ${ }^{2}$ Universidade Federal da Paraíba, João Pessoa, PB, Brasil \\ ${ }^{3}$ Instituto Superior de Educação da Paraíba, João Pessoa, PB, Brasil
}

\begin{abstract}
Utilizing the structural approach of the Social Representations Theory, which allows an order and understanding of the reality lived by individuals/groups, this study intends to identify the central nucleus and peripheral systems of the Social Representations of Vitiligo, as well as the representational structure of the self-image that people with the affection possess. For this, 370 Brazilians with Vitiligo from all regions of Brazil, aged from 18 to $67(M=35.71, S D=12.11)$ and predominantly female $(80.7 \%)$, were enrolled in a study through the online completion of a social-demographic questionnaire and the Free Word Association Technique (FWAT). In the FWAT, participants' responses were stimulated using the inductors "Vitiligo" and "Myself", the latter being related to the self-perception that the person with the disease experiences. The data were analyzed using prototypical lexicographic analysis, performed by the Evocation 2000 software. The results indicated, from the prominence of psychosocial evocations in the representational structure of Vitiligo and the participants' self-image, that Vitiligo's effects are not restricted to the skin, but overlap and negatively affect the social experience and self-concept of people with the disease.
\end{abstract}

Keywords: Social representations, vitiligo, self-image, representational structure.

\section{Estrutura Representacional do Vitiligo: Marcas que Não se Restringem à Pele}

\section{Resumo}

Utilizando-se da abordagem estrutural da Teoria das Representações Sociais, que permite uma ordem e compreensão da realidade vivida por indivíduos/grupos, intenta-se, no presente estudo, identificar o núcleo central e sistemas periféricos das Representações Sociais do Vitiligo, bem como a estrutura

* Mailing address: Ponta Delgada Street, 56 R/C, Lisboa - Portugal. Code Post: 1000-243. Phone: +351 91375 8142. E-mail: dobuemerson@gmail.com

Financial support: National Council for Scientific and Technological Development (CNPq). 
representacional da autoimagem que pessoas com a afecção possuem. Para tanto, participaram do estudo 370 brasileiros com Vitiligo de todas as regiões do Brasil, com idades de 18 a 67 anos $(M=35,71$; $D P=12,11)$, prevalentemente do sexo feminino $(80,7 \%)$, por meio da resolução online de um questionário sociodemográfico e da Técnica de Associação Livre de Palavras (TALP). Destaca-se que, na TALP, a evocação de respostas dos participantes foi dada a partir dos estímulos indutores "Vitiligo" e "eu mesmo", estando o último relacionado à percepção que a pessoa com a doença tem sobre si mesma. Os dados foram analisados a partir da análise lexicográfica prototípica desempenhada pelo software Evocation 2000. Os resultados indicaram, através da proeminência de evocações de ordem psicossocial na estrutura representacional do Vitiligo e autoimagem dos participantes, que as marcas de Vitiligo não se restringem à pele, mas sobrepõem-se a esta, uma vez que as possuir afeta negativamente a vivência social e autoconceito das pessoas com a afecção.

Palavras-chave: Representações sociais, vitiligo, autoimagem, estrutura representacial.

\section{Estructura Representacional del Vitiligo: Marcas que No se Restringen La Piel}

\section{Resumen}

Utilizando el enfoque estructural que permite un orden y una comprensión de la realidad vivida por individuos/grupos, el objetivo del presente estudio es identificar los elementos centrales y periféricos de las Representaciones Sociales del Vitíligo, así como la estructura representacional de la autoimagen que las personas con la enfermedad tienen. Para eso, 370 brasileños con Vitiligo de todas las regiones de Brasil, de 18 a 67 años, predominantemente mujeres (80,7\%), se inscribieron en el estudio a través de la resolución en línea de un cuestionario sociodemográfico y el Técnica Libre de Asociación de Palabras (TLAP). Se resalta que que en el TLAP las respuestas de los participantes fueron dadas por los inductores "Vitiligo" y "yo", este último relacionado con la percepción que tiene la persona con la enfermedad sobre sí mismo. Los datos se analizaron en base al análisis lexicográfico prototípico realizado por el software Evocation 2000. Los resultados indicaron, a través de la prominencia de las evocaciones psicosociales en el vitíligo y la estructura de representación de la autoimagen que las manchas de Vitiligo no se restringen a la piel, sino que se superponen con ésta, ya que afectar negativamente la experiencia social y la autoconcepto con la enfermedad.

Palabras clave: Representaciones sociales, vitíligo, autoimagen, estructura representacional.

Vitiligo affects between 0.5 to $2 \%$ of the world's population, compromising both men and women with no specific prevalence concerning skin color or age range. It has a complex and non-consensual etiology and is characterized by the reduction and/or loss of the melanocytes function (responsible cells for the melanin production in the skin), that causes localized or generalized formation of acromial patches, in an instable progression (Bonotis et al., 2015; Mufaddel \& Abdelgani, 2014; Ongenae, Dierckxsens, Brochez, van Geel, \& Naeyaert, 2005; Steiner, Bedin, Moraes, Villas, \& Steiner, 2004).
If localized, Vitiligo is focally expressed, and in many cases difficult to be perceived in the social context due to the size and location of macules/patches in body areas which may be easily camouflaged by the use of clothing and/or makeup. If a generalized manifestation occurs, the condition can become acrofacial (distal part of the extremities and face), vulgar (randomly distributed achromic macules), or mixed (acrofacial and vulgar), which is most easily noticed by people in the social dynamic (Pahwa, Mehta, Khaitan, Sharma, \& Ramam, 2013).

Although there is an increase in the research development in the national and international 
scenario in the last decades on the subject, these, to a large extent, point out only to the need for more systematic and verifiable studies that explain which biological factors are predictive of the onset and the condition progression (Akrem, Baroudi, Aichi, Houch, \& Hamdaoui, 2008; AlGhamdi, 2010; Antelo, Filgueira, \& Cunha, 2008; Dellatorre, Bertolini, \& Castro, 2017; Khurrum, \& AlGhamdi, 2017; Lerner, 1959; Njoo \& Westerhof, 1997; Panda, 2005; Prasad \& Bhatnagar, 2003; Rosa \& Natali, 2009). For focusing on the Vitiligo's pathophysiological characteristics, such studies eventually disregard the psychosocial implications of changes in lifestyle that the disease causes, given the individual's self-perception and self-conception changes, the increase in experiences with tension and anxiety states (since the prognosis for Vitiligo is unknown), modifications in the individual's social dynamics and the need to deal with prejudice expressed in curious glances at the white patches, adverse comments, and retreats from regular touching (Do Bú, Alexandre, Scardua, \& Araújo, 2018; Müller \& Ramos, 2004; Sant'Anna, Giovanetti, Castanho, Bazhuni, \& La Selva, 2003; Silva, Castoldi, \& Kijner, 2011).

Conceptually addressing prejudice, Allport (1954) suggests that it is characterized as a negative attitude of an individual directed at groups or their members, simply because they belong to different social groups. On the other hand, from a societal perspective as developed by Doise (1982) and ratified by Camino (1996, 1998), prejudice is organized around intergroup relations of power. In these power relations, intergroup dynamics are not only explained in individual motivations terms, but as a product of socio-historically constructed ideological representations that justify expression of negative and derogatory attitudes, together with hostile and discriminatory behaviors.

To establish a relation concerning the sociohistorical understanding of what Vitiligo may represent in the social imaginary in different cultures, to what would justify the population prejudice towards people with the disease, it is suggested that the frequently mistaken way throughout history that Vitiligo has been confused with leprosy, mainly in sacred books of different cultures is casual (Do Bú, Alexandre \& Coutinho, 2017; Müller, 2005).

In this sense, the aforementioned scenario demonstrates the imperative character of a proximal proposal among the health, human and social sciences, since a scope of this nature can make possible the multidimensionality interpretation of the skin affections, especially of Vitiligo, extrapolating the limits of the biomedical model pragmatism, whose discourse is limited to only biological triggers and progressors. In this perspective, considering the importance of subjectivity in thoughts about everyday life as related to health issues (Oliveira, 2000); the theoretical framework of this article takes as a central reference the psychosociological perspective, namely Social Representation Theory - SRT (Abric, 1994; Moscovici, 2011, 2012).

In general, Social Representations (SRs) are understood as symbolic and practical sets, whose status is that of construction and not of reproduction. They are characterized by their selection of information, from the repertoire circulating in society, in an attempt to interpret reality (Moscovici, 2011, 2012). Due to the inherent plurality within SRs, trying to define them becomes a complex task insofar as this alone may limit their conceptual reach. However, according to Moscovici (1981), SRs are a "set of concepts, propositions and explanations originating in everyday life in the course of interpersonal communications". SRs are thus established as a form of socially elaborated and shared knowledge, which seeks to contribute to the reality construction common to a social group (Jodelet \& Moscovici, 1989).

Social Representation Theory starts from the premise that there are two ways of knowing reality and of communicating; guided by different objectives: the consensual (common sense); and the reified (scientific). The consensual universe would be that which is constituted mainly of informal conversation and common sense, whereas the reified universe would be the scientific space. Both, despite having differing 
purposes are effective and indispensable for human life (Arruda, 2002; Chaves \& Silva, 2011). Following this reasoning, common-sense knowledge ceases to be considered "disjointed", and gains meaning (Nóbrega, 2001). It can be seen that SRs are not only made up of scientific theories, but also of experiences, everyday communications, facts, and of the culturally shared hubs (Vala, 2000). It is worth noting that common-sense knowledge is not synonymous with ignorance, but rather, it is the logic by which all - erudite and illiterate, scientists or common folk - build knowledge of their relationships and activities in daily life (Araújo, 2017).

In short, SRs are built to help make the unfamiliar, familiar, and to give sense to the real. In addition to this, Abric points out that SRs function as knowledge (allowing understanding and explaining reality), as identity (defining identity and allowing the group specificity protection), as orientation (to guide behaviors and practices), and as justification (allowing a posteriori, justification for positions and behaviors; Abric, 1994, 1998; Cavalcante, 2017; Vala, 2000).

For Abric (1994, 1998, 2003), SRs are structured in two types of elements or complementary systems: the Central Nucleus, which correspond to the stable and consensual parts of SRs, whose function is to generate basic meanings in representation and determine the global organization for all the elements. This define the group homogeneity, relating to its collective history, and determining the representation organization; and the Peripherals, which have a more flexible character, allowing adjustment to contextual changes, adaptation to concrete reality, differentiation of the content represented, and in historical terms, the centralized system protection. Both are sensitive to circumstances, help integrate individual experiences, and manifest group heterogeneity.

It is worth noting, therefore, that SRT unfolds into different theoretical-methodological currents: the dimensional approach, coined by Moscovici, in 1961, is characterized as prioritizing the study of the genesis and process of SR construction; and the structural approach as proposed by Jean-Claude Abric in 1976, which points out that SRs are organized internally, having a central nucleus and peripheral elements - the first one being responsible for the creation and/or transformation of the meanings of the other essential SR elements (Almeida \& Cunha, 2003; Chaves \& Silva, 2011; Coutinho \& Saraiva, 2013).

Using the SRT dimensional approach to a holistic understanding of Vitiligo, we highlight the three solitary Brazilian studies existence, found in the national and international literature (Andrade, Ferraz, Coelho, \& Pinto, 2016; Do Bú et al., 2017; Szabo \& Brandão, 2016). These seek, from the realities of those afflicted by the disease, to understand the constructed and socially shared meanings developed in the face of this event. It should be noted that such studies present not only a response of the individual's perception to the context in which he/she is inserted, but, in addition, show the symbolic construction about Vitiligo that is permeated by the social understanding of the disease.

There are no studies in the literature that use an SRT based in the structural approach to comprehend/understand the realities experienced by Vitiligo sufferers. From this analysis we can determine significant aspects to the internal SR order, structure and organization concerning the disease. Thus, the present study aimed to identify the central nucleus and peripheral SRs elements of Vitiligo, as well as the representational structure of the self-image that people with the disease carry.

\section{Method}

This was a quantitative-qualitative, descriptive-exploratory study, anchored in the theoretical contribution of the structural approach of the Social Representations Theory.

\section{Participants}

The sample was composed of 370 random Brazilians with Vitiligo, aged 18 to $67(M=35.71$, $S D=12.11)$, predominantly female $(80.7 \%)$, 
primarily residents of the Southeast (35.4\%) and South $(19.7 \%)$ of the country, which were involved in groups related to the theme of Vitiligo on the Facebook social network. The inclusion criteria were: having Vitiligo (diagnosed by a dermatologist); be over 18 years of age; be Brazilian; willing to participate in the research on a voluntary basis.

\section{Instruments}

An online form divided in two parts was used for data collection: the first part entitled "Social-Demographic Questionnaire", included questions related to age, sex, income, schooling and the area of Vitiligo macules/patches exposure. The second part applied the "Free Word Association Technique" (FWAT). The Socialdemographic characteristics of the participants in this study are shown in detail in Table 1.

Table 1

Social-Demographic Characteristics of Participants with Vitiligo

\begin{tabular}{|c|c|c|}
\hline Variável & & $(\%)$ \\
\hline \multirow{4}{*}{ Skin color } & White & 53,4 \\
\hline & Black & 11,0 \\
\hline & Brown & 32,9 \\
\hline & Indian & 2,7 \\
\hline \multirow{4}{*}{ Education } & Elementary & 18,5 \\
\hline & High school & 40,7 \\
\hline & College & 20,1 \\
\hline & Post-graduation & 20,7 \\
\hline \multirow{4}{*}{ Age range } & 18 to 28 years old & 31,5 \\
\hline & 29 to 39 years old & 27,8 \\
\hline & $40-50$ years old & 20,3 \\
\hline & Over 50 years old & 20,4 \\
\hline \multirow{5}{*}{$\begin{array}{l}\text { Concentration of participants } \\
\text { by Region of Brazil }\end{array}$} & North & 8,6 \\
\hline & Northeast & 17,4 \\
\hline & Central-West & 18,9 \\
\hline & Southeast & 35,4 \\
\hline & South & 19,7 \\
\hline \multirow{3}{*}{ Vitiligo exhibition area } & Easy Perception by the Social Environment (EPSE) & 55,6 \\
\hline & Imperceptible to the Social Environment (ISE) & 11,1 \\
\hline & Both (EPSE; ISE) & 33,3 \\
\hline
\end{tabular}

Note. $(N=370 ; \%=$ percentage $)$.

It is important to point out that the FWAT, a projective technique; is structured on evocation of responses by the participants to given inductors that are previously defined by the researcher. This permits emphasis of semantic universes related to the given object (Araújo, 2017; Coutinho \& Do Bú, 2017). The inducing stimuli for evocations were: "Vitiligo" and "Myself", the latter being related to the diseased participants' perception concerning themselves.

\section{Data Collection Procedures}

With the Google Drive virtual platform help a form was created with the above-mentioned tools. The form was then established in groups related to Vitiligo on Facebook (for 15 days). In the form, the request was made to complete the questionnaire, informing the participants about the criteria for inclusion in the study, the average time for the questionnaire completion (four minutes), and the anonymity and confidentiality 
concerning their answers. It is emphasized that the participants agreement in the initial part of the questionnaire was required, where which one might choose, after receiving the Free and Informed Consent (FIC), to participate or not in the research.

\section{Data Analysis Procedures}

The Evocation 2000 software (EVOC) was used to develop prototypical lexicographic analyses of the collected material (Araújo, 2017). In order to understand the representational structure of Vitiligo, as well as the self-image of people "imprinted by the white", the analyses involved creation of four quadrants, providing each evoked term with its respective frequency (F), and the mean order of evocation (response) of the participants (MOE). This made it possible to access the representational structures of the objects.

According to Sá (2002), these two criteria combination (frequency and mean order of each word's evocation) allows removal of evocations that belong to the central nucleus and peripheral systems of the representation, due to their prototypical character or prominence (Moliner, 1994). Thus, intersections between these criteria generate four quadrants with different degrees of centrality to the words that constitute them (Sá, 2002). It should be noted that in the prototypical analysis as performed by EVOC, the first quadrant (upper left) presents the words that had high frequency (greater than average) and low mean order of evocation (which were first evoked), being an indicator of the central nucleus of the representation. The second quadrant (upper right) and third quadrant (lower left) consist of the near peripheral system, indicating higher frequency terms, yet that were not readily evoked. Finally, the fourth quadrant (lower right) demonstrates the distant peripheral system, with words that obtained less frequency and that were not promptly evoked (Camargo \& Justo, 2013; Dias, 2017).

\section{Ethical Procedures}

The data were only collected after authorization by the Ethics Committee on Research
Involving Human Beings, located at the Health Sciences Center from the Federal University of Paraíba, with report number 2.190.296 and Certificate of Presentation for Ethical Appreciation 69729117.8.0000.5188, with the appropriate authorization of each participant, according to the Resolution n. 466 of the National Health Council (2012).

\section{Results and Discussion}

Theresults oftheprototypicallexicographical analyses performed using the EVOC software will here be presented. On presenting the tables referring to each analysis, a discussion of the findings, considering the pertinent literature on the subject will also be made.

\section{Analysis of the Stimulus "Vitiligo"}

The analysis of the first inducer stimulus (Vitiligo) considered a total of 1.281 words evoked, of which 333 were differing. Figure 1 , presents the results of this stimulus, and was created based on the minimum frequency of twenty (20), and with the Mean Order of Evocation being two (2.0); as analytical criteria.

It is found that in the upper left quadrant, the representational object Vitiligo emerged associated with the words prejudice, sadness and shame. In general terms, this quadrant encompasses the cognitions most susceptible to harboring the core of a representation, since it agglutinates the evocations most frequently and readily evoked by social actors (Sá, 2002). In this process of social perception, Abric (1994) advocates that the central/constitutive elements of social thought allow an understanding of the reality lived by individuals or groups, from which one can know the aspects of their meaning and internal organization.

In the quadrant in question, the prominence of psychosocial evocations related to Vitiligo in contrast to the biological characteristics commonly exposed in the biomedical literature undoubtedly highlight the Social Psychology importance to detailed analysis of the subject. From this perspective, it is evident that the SR central nucleus for Vitiligo underlines the 


\begin{tabular}{|c|c|c|c|c|c|}
\hline \multicolumn{3}{|c|}{ CENTRAL NUCLEUS } & \multicolumn{3}{|c|}{$\begin{array}{c}\text { NEXT PERIPHERAL } \\
\text { SYSTEM }\end{array}$} \\
\hline $\mathrm{F} \geq 20$ & \multicolumn{2}{|c|}{$\mathrm{MOE}<2.0$} & $\mathrm{~F} \geq 20$ & \multicolumn{2}{|r|}{$\mathrm{MOE} \geq 2.0$} \\
\hline Word & $\mathbf{F}$ & MOE & Word & $\mathbf{F}$ & MOE \\
\hline sadness & 73 & 1.887 & acceptance & 52 & 2.365 \\
\hline shame & 62 & 1.774 & cure & 42 & 2.286 \\
\hline \multirow[t]{8}{*}{ prejudice } & 60 & 1.983 & spotted & 39 & 2.282 \\
\hline & & & disease & 39 & 2.205 \\
\hline & & & fear & 34 & 2.441 \\
\hline & & & ugly & 33 & 2.424 \\
\hline & & & self-esteem & 27 & 2.556 \\
\hline & & & skin & 27 & 2.481 \\
\hline & & & hope & 21 & 2.810 \\
\hline & & & love & 20 & 2.050 \\
\hline \multicolumn{3}{|c|}{$\begin{array}{c}\text { NEAR PERIPHERAL } \\
\text { SYSTEM }\end{array}$} & \multicolumn{3}{|c|}{$\begin{array}{c}\text { DISTANT PERIPHERAL } \\
\text { SYSTEM }\end{array}$} \\
\hline $19<F \geq 10$ & \multicolumn{2}{|c|}{$\mathrm{MOE}<2.0$} & $19<F \geq 10$ & \multicolumn{2}{|r|}{$\mathrm{MOE} \geq 2.0$} \\
\hline Word & $\mathbf{F}$ & MOE & Word & $\mathbf{F}$ & MOE \\
\hline depression & 18 & 1.263 & melanin & 15 & 2.867 \\
\hline family & 17 & 1.647 & overcoming & 13 & 2.615 \\
\hline alone & 15 & 1.938 & emotional & 12 & 2.667 \\
\hline pain & 15 & 1.133 & different & 11 & 2.120 \\
\hline anxiousness & 14 & 1.932 & anger & 10 & 2.800 \\
\hline treatment & 14 & 1.854 & bothersome & 10 & 2.667 \\
\hline \multirow[t]{2}{*}{ exclusion } & 14 & 1.714 & insecurity & 10 & 2.429 \\
\hline & & & autoimmune & 10 & 2.200 \\
\hline
\end{tabular}

Figure 1. Representational structure facing the stimulus "Vitiligo".

condition implications that go beyond the limits of the skin itself, being associated to a disqualified social experience, due to prejudice and/or shame, while sadness is probably a potent feeling in this process.

The near peripheral systems are presented in the upper right and lower left quadrant, which allow for both the meanings and protection of the central system, integrating individual experiences and histories, and therefore group heterogeneity (Shimuzu, Silva, Moura, Bermúdez, \& Odeh, 2015). Here, the elements observed were: acceptance, love, self-esteem, cure, illness, hope, ugly, stain, fear, skin, depression, family, pain, loneliness, exclusion, treatment, and anxiety. These words give dynamicity to the SR of Vitiligo in everyday life, assigning important meanings to the representational nucleus of the object, reiterating that its function cannot be understood, except in continuous dialogue with its periphery (Sá, 2002).

Thus, the conditional character of the most salient cognitions in the SR of Vitiligo (prejudice, shame, and sadness) becomes understandable; these cognitions receive sustenance and meaning from the daily experiences of the social actors, who emphasized that their disease as expressed in skin patches is commonly associated with "ugliness", fear, and exclusion.

This finding seems to provoke, as observed in the lower left quadrant, anxiety, pain, loneliness and depression. In this scenario socio-familial support for these individuals, can be equally important for facing both medical treatments, and the re-signification involved in being "imprinted by the white". On the other hand, this same experience of suffering seems to demand of people with Vitiligo and their social surroundings a new and necessary attitude. As 
the upper right quadrant points out, a positive posture of love and acceptance is capable of nourishing Vitiligo sufferers' self-esteem and their hopes for healing.

In the distant peripheral system, placed in the right lower quadrant, the participants objectified Vitiligo through the words overcoming, autoimmune, different, emotional, melanin, anger, annoyance and insecurity. According to Abric (2003), the peripheral elements have the function of concretizing the central elements in order to guide the practices and behaviors of the participants. In this sense, it can be affirmed that the peripheral system, as distant from the representational structure of Vitiligo has evocations that anchor the disease to both biological knowledge and psycho-sociological factors which demand successful overcoming; this, besides suggesting the different view of Vitiligo in the social environment as generator of annoyance, anger and insecurity.

Szabo and Brandão (2016) studied people with Vitiligo seeking to verify SRs in their experiences with "the white patches" and corroborated the findings of the present research where the experience is anchored to biological, psychological and social aspects. The findings were also reinforced since these authors (in sampling a smaller population of sixteen participants) in a specific context (Rio de Janeiro - Brazil), identified that people with Vitiligo, when establishing social relations in daily life were reporting suffering prejudice.

In the same sense, Andrade et al. (2016) verified that participants in their research, when referring to the condition, consensually objectified it through the words prejudice, stigma and discrimination. Vitiligo appears as a preponderant factor in social exclusion, probably due to its anchoring with leprosy in the social imaginary, as well as to the belief that it must be a contagious disease (Donata, Kesavan, \& Austin, 1990; Goldman, Richard, \& Moraites, 1966; Müller, 2005; Njoo \& Westerhof, 1997; Panda, 2005; Prasad \& Bhatnagar, 2003). Thus, in the future, more systematized studies are proposed, this time trying to prove or refute such hypothesis in the general population.
For people with Vitiligo, the changes in the surface of the skin caused by the condition are related to social exclusion. Goffman (2008) affirms and is supported by Costa (2017) concerning "physical deformities", which when easily perceived, call attention of the population to characteristics which deviate from the accepted standards. This can provoke differentiations; e.g. I have "normal" skin (ingroup), and the other has a "patched" skin (outgroup), which can easily lead to both discrimination and hostility - as a result of prejudice - in those without the disease when addressing the person with Vitiligo.

Do Bú et al. (2018), indicates that eight participants under study attested to prejudice, (due to Vitiligo's conspicuousness), either directly (pejorative comments and/or retreat from touching), or camouflaged (as in curious looks). From this perspective, one may discuss flagrant and subtle prejudice, in which the former is expressed through hostility directed towards the member of the other group, considering the member as belonging to a weaker or lower group; while the latter manifests itself as a justified discourse and seemingly positive behaviors are activated, yet permeated by the same ideology underlying flagrant prejudice (Pettigrew \& Meertens, 1995). Thus, although the two prejudice forms assume different manifestations, they both rely on ideological beliefs/representations concerning the inferiority of the outgroup; which are then used to reinforce social inequality.

In summary, once people are categorized in groups (for example, people with Vitiligo), they are assigned stereotypes originating in the social representations of the perceiver (a person without Vitiligo), this leads to social comparisons used to maintain social identity within the group without Vitiligo. Stereotypes concerning the disease, when forged in the social context, and as presented in the content evoked from the social actors involved in this study, have an impact on behavior and can result in prejudice and discrimination as a consequence.

Do Bú et al. (2017), studying SRs in 196 Brazilians with Vitiligo, concerning what would the disease be to them, identified that elements 
such as prejudice, disease, psychological, autoimmune, melanin, skin, lack, self-esteem, stain and depigmentation were frequently used as references to the whitish macules. Moreover, even in low frequencies, the terms weakened, troubled, constrained, embarrassment, annoyance, sadness, and horrible were also used. Such findings were also evidenced in this research, and indicate an appropriation and use (by participants in the present study) of reified theory (biomedical knowledge) to explain Vitiligo. In addition it points out the consensual way in which Brazilians represent the disease.

We also highlight that the anxiety evidenced in the evocations of the social actors as participants in the present study, has also been identified in participant's speeches in research conducted by Do Bú et al. (2018), who emphasized the belief that emotional factors are related to the onset and progression of Vitiligo. However, on this point, the literature does not present consensus, and it is principally argued that the disease affects the individual's quality of life, resulting in low self-esteem, psychiatric comorbidities, sadness, fear, insecurity and anger (Ajose, Parker, Merrall, Adewuya, \& Zachariah, 2014; Bonotis et al., 2015; Correia \& Borloti, 2013; Pahwa et al., 2013; Sarham, Mohammed, Gomaa, \& Eyada, 2016).

\section{Analysis of the Stimulus "Myself"}

Analysis of the SR structure and the self-image of the participants, accessed from evocations related to the inducer stimulus "Myself", revealed a total of 1.233 evoked words of which 344 were distinct.

\begin{tabular}{|c|c|c|c|c|c|}
\hline \multicolumn{3}{|c|}{ CENTRAL NUCLEUS } & \multicolumn{3}{|c|}{ NEXT PERIPHERAL SYSTEM } \\
\hline $\mathrm{F} \geq 20$ & \multicolumn{2}{|c|}{$\mathrm{MOE}<2.2$} & $\mathrm{~F} \geq 20$ & \multicolumn{2}{|r|}{$\mathrm{MOE} \geq 2.2$} \\
\hline Word & $\mathbf{F}$ & MOE & Word & $\mathbf{F}$ & MOE \\
\hline shamed & 42 & 1.976 & sad & 72 & 2.222 \\
\hline ugly & 42 & 2.119 & depressed & 36 & 2.833 \\
\hline \multirow[t]{6}{*}{ fearful } & 34 & 1.912 & accepted & 31 & 2.290 \\
\hline & & & excluded & 26 & 2.500 \\
\hline & & & spotted & 24 & 2.458 \\
\hline & & & different & 23 & 2.565 \\
\hline & & & anxious & 22 & 2.682 \\
\hline & & & sick & 20 & 2.600 \\
\hline \multicolumn{3}{|c|}{$\begin{array}{c}\text { NEAR PERIPHERAL } \\
\text { SYSTEM }\end{array}$} & \multicolumn{3}{|c|}{$\begin{array}{c}\text { DISTANT PERIPHERAL } \\
\text { SYSTEM }\end{array}$} \\
\hline $19<\mathrm{F} \geq 10$ & \multicolumn{2}{|c|}{$\mathrm{MOE}<2.2$} & $19<\mathrm{F} \geq 10$ & \multicolumn{2}{|c|}{$\mathrm{MOE} \geq 2.2$} \\
\hline Word & F & MOE & Word & $\mathbf{F}$ & MOE \\
\hline insecure & 17 & 2.176 & loved & 19 & 2.421 \\
\hline pretty & 16 & 1.750 & hopeful & 18 & 2.778 \\
\hline self-esteem & 13 & 2.154 & sensitive & 17 & 2.765 \\
\hline \multirow[t]{11}{*}{ strange } & 13 & 2.077 & happy & 16 & 2.250 \\
\hline & & & cure & 15 & 3.000 \\
\hline & & & strong & 15 & 2.267 \\
\hline & & & prejudice & 14 & 2.286 \\
\hline & & & treatment & 13 & 2.385 \\
\hline & & & white & 11 & 2.818 \\
\hline & & & dirty & 11 & 2.545 \\
\hline & & & emotional & 11 & 2.455 \\
\hline & & & frustrated & 10 & 2.600 \\
\hline & & & shy & 10 & 2.500 \\
\hline & & & fervent & 10 & 2.300 \\
\hline
\end{tabular}

Figure 2. Representational structure facing the stimulus "myself". 
Figure 2 was constructed on the basis of a minimum frequency of 20 and a mean order of evocation of 2.2. It shows a central nucleus (upper left quadrant) organized around the elements: ashamed, ugly and fearful. In the near peripheral systems, evidenced in the upper right and lower left, giving support and meaning to the representational center previously exposed, the participants self-image was associated with the following elements: acceptance, anxious, depressed, different, sick, excluded, stained, sad, self-esteem, beautiful, strange and insecure.

With regard to the distant peripheral system, located in the lower right quadrant, the social actors with Vitiligo self-image was objectified through the evocations: loved, white, healing, emotive, hopeful, happy, fervent, strong, frustrated, prejudiced, sensitive, dirty, and shy.

Relating such evocations to the basic characteristic of membership in a (Vitiligo) group; and to the social representations that these participants nurture concerning the object (synonymous with prejudice, shame and sadness), the representational structure of the image that social actors construct concerning themselves (ashamed, ugly and fearful), becomes completely understandable. It is a representation that is largely related to negative elements that justify how the participants in this study understand and explain their condition; define and protect their identity - as a group of people who have Vitiligo - and, from this, orient their practices and justify their positions and behavior, either in the way they deal with the disease, or with the social environment (Abric, 1994, 1998; Cavalcante, 2017; Vala, 2000).

These results call for reflection concerning the construction processes of self-concept and self-image in the social actors participating in the present study. Working with the concept of self-conception, Faria (2005) argues that it is a result of social construction, the product of a history of social reinforcement directly related to self-recognition (through the other) or from self-recognition as learned from others. Approximating the concept of construction and or transmutation of the corporeal image produced through lived experience; Araújo (2017, p.
33) confirms that the image has meaning and "receives a body in the everyday social life".

Thus, considering that construction of both the self-concept and self-image of a person are associated with evaluations realized and originating in social relations and socially instituted body standards, Vitiligo brings negative values (Do Bú et al., 2018). It is evident from the results of this research that the effects of the disease are not restricted to the skin of those who have it, but, eminently overlap as psychosocial marks. Thus, having "white patches" in a stigmatizing and prejudiced social dynamic, negatively affects one's self-image and self-esteem, causing the self-deprecating feelings characteristic of self-stigmatization.

Our results are consistent with studies dealing with implications found with dermatitis, in which the self-esteem and quality of life of people with dermatological alterations are impaired due to a sensation of transmitting a negative image to other people (Ajose, et al., 2014; Azevêdo, 2016; Correia \& Bortoli, 2013; Noh, Kim, Park, Hann \& Oh, 2013). Szabo and Brandão (2016) also show that the concerns of men and women having Vitiligo are related to the transfigurations that the disease causes, and share dysfunctional beliefs that the disease makes them less attractive to their loving partners, and constitutes an impediment to obtaining one.

In this respect, it is known that mass communication tends to disseminate ideas and values to the population which relate a normative standard of beauty - thin, tall, slender bodies, free of marks and "imperfections" - influencing their visions of the world, and consequently social practices that begin with discrimination and exclusion of people who depart from what is established as beautiful (Araújo, 2017; Camargo, Goetz, \& Barbará, 2005; Camargo, Goetz, Barbará, \& Justo, 2007). Thus, the way in which the social actors in this study represent Vitiligo and their self-images are especially associated with what is transmitted in the media concerning what is beautiful and is given as "normal", making it possible to construct and share representations linked to feeling of ugliness, shame, filth, frustration, and exclusion, 
as well as a certain strangeness to the detriment of people who are not "stained."

In general terms, the findings suggest that, although the social actors' self-image is subordinated to the social condition of deterioration (ugly), and fear, - justified by elements such as prejudice and difference, as well as by emotional states of anxiety, sadness, insecurity and depression - we also ambivalently observed elements pointing to an impression of Vitiligo as being a unique way to be human, which can have its own beauty, this though lacking the acceptance in possessing the disease as not only of itself and for itself, but above all, in the social environment.

It is worth reflecting, then, how Vitiligo SRs are forged and structured in the triad: object (Vitiligo), ego (person with Vitiligo) and alter (culture) (Marcová, 2006; Moscovici, 2012); the conception of "what Vitiligo is", is constructed from the relation of the individuals to the disease and their social environments. This dictates what is beautiful and adequate, through normative standards. For the individual, continuous relationships of self-originating prejudice are generated against one's self as well by the individual's social environment. Prejudice, therefore, runs through the SRs of Vitiligo, presenting itself as the result of such representations.

Although the data presented show sexual percentage differences $(80.7 \%$ female prevalence), the research indicates directions for new more systematized studies on the subject, involving different theoretical currents. Such studies should aim to identify if elements such as: sensitivity, shyness, emotionality, anxiety and melancholy, as evidenced in the selfimage SRs of the social actors in this study, are characteristic aspects within the personalities of these people, that demand kindness and social acceptance.

The predominance of people with white skin color is also highlighted as a limitation of the present study. This may be related to the fact that the data collection of the present research occurred digitally, involving differing factors (such as economic), since not all people of different skin tones have access to the internet. It is important that future studies also seek homogeneity as to study participants' level of education, since in this study a prevalence of people with medium and higher levels of education was observed, a sample that does not represent Brazilian education well, but rather who accesses Brazilian social networks.

In addition, for using software such as Alceste, IRAMUTEQ and/or Tri-Deux-Mots to perform factorial analyses of correspondence in the collected material, we suggest that, in future research, be used regional, social, sex and skin color as intervening variables of the participants for the structuring Vitiligo's SRs, so their understanding can be broadened. This is suggested since it is well understood that SRs are closely related to the groups to which the subject belongs (Moscovici, 2012). It is necessary to consider, for example, if there are differences between the representations of the affection elaborated by men and women, young and old, poor and rich, southerners and northerners, with white spots that are easy to perceive or not to the social environment, among others.

\section{Final Considerations}

Identification of the representational structure of a given object serves among other things to guide behavior when confronting it. The structures of the SRs of Vitiligo identified here point to an organization focused on negative psychosocial implications for those who possess the disease. This study emphasizes the need for specialized care for people with Vitiligo, with a holistic focus on the skin disease processes. This care should be expanded and shared among health professionals, in an inter/trans-disciplinary way, taking into account the meaning of skin disease and not only seeing symptoms.

In this sense, the marks of the disease do not present themselves as the biomedical literature commonly portrays them: as asymptomatic "changes", - but they "scream" and upon breaking the silence, express a life history, a place of belonging: a context. It is therefore suggested that therapeutic practice begins to consider the 
uniqueness of people with Vitiligo, the context into which these people are inserted and the subjectification modes that come from their white marks as social and symbolic expressions that go beyond simple dermatological entities.

In addition, with the objective of reducing prejudice and discrimination against the "imprinted by the white" people, formulation of public policies to raise awareness among the general population (psycho-educational practices) about "what Vitiligo is" becomes necessary. It is believed that especially through the media, such policies will allow the general population (including those with the condition) to redefine Vitiligo's constructed and shared meanings; promoting Vitiligo affected skin as one of many forms of being in the world.

\section{References}

Abric, J. C. (1994). Pratiques sociales et représentations. Paris: Presses Universitaires de France.

Abric, J. C. (1998). A abordagem estrutural das representações sociais. In A. S. P. Moreira \& D. C. Oliveira (Eds.), Estudos interdisciplinares em representações sociais (pp. 27-38). Goiânia, $\mathrm{GO}: \mathrm{AB}$

Abric, J. C. (2003). Abordagem estrutural das representações sociais: Desenvolvimentos recentes. In P. H. F. Campos \& M. C. Loureiro (Eds.), Representações sociais e práticas educativas (pp. 37-57). Goiânia, GO: Universidade Católica de Goiás.

Ajose, F. O. A., Parker, R. A., Merrall, E. L. C., Adewuya, A. O., \& Zachariah, M. P. (2014). Quantification and comparison of psychiatric distress in African patients with albinism and vitiligo: A 5-year prospective study. Journal of the European Academy of Dermatology and Venereology, 28, 925-932. doi: 10.1111/ jdv.12216

Akrem, J., Baroudi, A., Aichi, T., Houch, F., \& Hamdaoui, M. H. (2008). Profile of vitiligo in the South of Tunisia. International Journal of Dermatology, 47, 670-674. doi: 10.1111/j.13654632.2008.03695.x

AlGhamdi, K. M. (2010). Beliefs and perceptions of Arab Vitiligo patients regarding their condition. International Journal of Dermatology, 49, 11411145. doi: 10.1111/j.1365-4632.2010.04514.x
Allport, G. W. (1954). The nature of prejudice. Reading, MA: Addison-Wesley.

Almeida, A. M. O., \& Cunha, G. G. (2003). Representações sociais do desenvolvimento humano. Psicologia: Reflexão e Crítica, 16(1), 147-155. doi: 10.1590/S010279722003000100015

Andrade, D., Ferraz, R. B. N., Coelho, A. B., \& Pinto, J. M. (2016). Avaliação do paciente com vitiligo frente as representações sociais acerca da doença. Revista UNILUS Ensino e Pesquisa, 13(31), 58-62. Retrieved from http://revista. unilus.edu.br/index.php/ruep/article/view/735/ u2016v13n31e735

Antelo, D. P., Filgueira, A. L., \& Cunha, J. M. T. (2008). Aspectos imunopatológicos do vitiligo. Medicina Cutânea Ibero-Latino-Americana, 36, 125-136. Retrieved from http://www. medigraphic.com/pdfs/cutanea/mc-2008/ mc083d.pdf

Araújo, L. S. (2017). Representações sociais da obesidade: Identidade e estigma (Doctoral dissertation). Retrieved from https://sigaa.ufpb. $\mathrm{br} /$ sigaa/verProducao idProducao $=529054 \& \mathrm{k}$ ey $=$ fb37bed3d875b666a2988e951256384a

Arruda, Â. (2002). Teoria das representações sociais e teorias de gênero. Cadernos de Pesquisa, 117(127), 127-147.

Azevêdo, I. F. M. (2016). Qualidade de vida, imagem corporal e qualidade de vida de pacientes com sequelas bucomaxolofaciais candidatos à reabilitação protética (Master's thesis). Retrieved from https://repositorio. ufrn.br/jspui/bitstream/123456789/21279/1/ IannyFelintoMedeirosDeAzevedo_DISSERT. pdf

Bonotis, K., Pantelis, K., Karaoulanis, S., Katsimaglis, C., Papaliaga, M., Zafiriou, E., \& Tsogas, P. (2015). Investigation of factors associated with health-related quality of life and psychological distress in vitiligo. Journal of German Society of Dermatology, 45-48. doi: 10.1111/ddg.12729

Camargo, B. V., Goetz, E. R., \& Barbará, A. S. (2005). Representação social da beleza de estudantes de Moda. In Anais da IV Jornada Internacional e II Conferência Brasileira sobre Representações Sociais (pp. 3353-3362). João Pessoa, PB: Universidade Federal da Paraíba.

Camargo, B. V., Goetz, E. R., Barbará, A., \& Justo, A. M. (2007). Representação social da beleza de estudantes de Educação Física e de 
Moda [Resumo] In Resumos de comunicações cientificas online, V Jornada Internacional e III Conferência Brasileira sobre Representações Sociais. Brasília, DF: Universidade de Brasília

Camargo, B. V., \& Justo, A. M. (2013). IRAMUTEQ: Um software gratuito para análise de dados textuais. Temas em Psicologia, 21(2), 513-518. doi: 10.9788/TP2013.2-16

Camino, L. (1996). Uma abordagem psicossociológica no estudo do comportamento político. Psicologia e Sociedade, 8, 16-42.

Camino, L. (1998). Direitos humanos e psicologia. In Comissão de Direitos Humanos, Conselho Federal de Psicologia (Ed.), Psicologia, ética e direitos humanos (pp. 39-63). Brasília, DF: Conselho Federal de Psicologia.

Cavalcante, J. G. (2017). Bullying e suas implicações na adolescência: Um estudo psicossociológico (Master's thesis). Universidade Federal da Paraíba, João Pessoa, PB, Brazil.

Chaves, A. M., \& Silva, P. L. (2011). Representações Sociais. In A. R. R. Torres (Ed.), Psicologia Social: Temas e teorias. Brasília, DF: Technopolik.

Correia, K. M. L., \& Borloti, E. (2013). Convivendo com o vitiligo: Uma análise descritiva da realidade vivida pelos portadores. Acta Comportamentalia, 21(2), 227-240. Retrieved from http://pepsic.bvsalud.org/scielo.php?pid= S018881452013000200006\&script=sci_arttext

Costa, J. A., Filho. (2017). Sexualidade no contexto da paraplegia: Um estudo das representações sociais (Doctoral dissertation). Retrieved from https://sigaa.ufpb.br/sigaa/public/programa/ defesas.jsf?lc $=$ pt_BR\&id $=2626$

Coutinho, M. P. L., \& Do Bú, E. A. (2017). A técnica de associação livre de palavras sobre o prisma do software tri-deux-mots (version 5.2). Revista Campo do Saber, 3(1), 219-243. Retrieved from http://periodicos.iesp.edu.br/index.php/ campodosaber/article/view/72/58

Coutinho, M. P. L., \& Saraiva, E. R. A. (2013). Teoria das representações sociais. In N. T. Alves (Ed.), Psicologia: Reflexões para ensino, pesquisa e extensão (pp. 73-114). João Pessoa, PB: Editora Universitária.

Dellatorre, G., Bertolini, W., \& Castro, C. C. S. (2017). Optimizing suction blister epidermal graft technique in the surgical treatment of vitiligo. Anais Brasileiros de Dermatologia, 92(6), 888890. doi: 10.1590/abd1806-4841.20176332
Dias, C. C. V. (2017). Mães de crianças autistas: Sobrecarga do cuidador e representações sociais sobre o autismo (Master's thesis). Retrieved from https://repositorio.ufpb.br/jspui/ bitstream/tede/9081/2/arquivototal.pdf

Do Bú, E. A., Alexandre, M. E. S., \& Coutinho, M. P. L. (2017). Representações sociais do vitiligo elaboradas por brasileiros marcados pelo branco. Psicologia, Saúde \& Doenças, 18(3), 760-772. http://dx.doi.org/10.15309/17psd180311

Do Bú, E. A., Alexandre, M. E. S., Scardua, A., \& Araújo, C. R. F. (2018). Vitiligo as a psychosocial disease: Apprehensions of patients imprinted by the white. Interface - Comunicação, Saúde, Educação, 22(65), 481-491. doi: 10.1590/180757622016.0925

Doise, W. (1982). L.explication en psychologie sociale. Paris: Presses Universitaires de France.

Donata, S. R., Kesavan, M., \& Austin, S. R. (1990). Clinical trial of certain ayurveda medicines indicated in vitiligo. Ancient Science of life, 4, 202-206. Retrieved from https://www.ncbi.nlm. nih.gov/pmc/articles/PMC3331338/pdf/ASL-9202.pdf

Faria, L. (2005). Desenvolvimento do auto-conceito físico nas crianças e nos adolescentes. Análise Psicológica,4(23),361-371.Retrievedfromhttp:// www.scielo.mec.pt/scielo.php?script $=$ sci_ arttext\&pid=S0870-82312005000400001

Goffman, E. (2008). Estigma - Notas sobre a manipulação da identidade deteriorada. Rio de Janeiro, RJ: LTC.

Goldman, L., Richard, S., \& Moraites, R. (1966). White spots in biblical times: A background for the dermatologist for participation in discussions of current revisions of the Bible. Archives of Dermatology, 93, 744-753. doi: 10.1001/ archderm.1966.01600240110023

Jodelet, D., \& Moscovici, S. (1989). Folies et représentations sociales. Paris: Presses Universitaires de France.

Khurrum, H., \& AlGhamdi, K. M. (2017). Prepubertal and postpubertal vitiligo: A multivariate comparative study in 375 patients. Anais Brasileiros de Dermatologia, 92(6), 811-815. doi: 10.1590/abd1806-4841.20176154

Lerner, A. B. (1959). Vitiligo. Journal of Investigative Dermatology, 32, 285-310. Retrieved from https://www.ncbi.nlm.nih.gov/ pubmed/13641799 
Marcová, I. (2006). Dialogicidade e Representações Sociais: As dinâmicas da mente. Petrópolis, RJ: Vozes.

Moliner, P. (1994). Les méthodes de repérage et d'identification du noyau des représentations sociales. In C. Guimelli (Ed.), Structures et transformations des représentations sociales (pp. 199-232). Neuchâtel, Switzerland: Delachaux et Niestlé.

Moscovici, S. (1981). La psychanalyse, son image et son public. Paris: Press Universitaires de France

Moscovici, S. (2011). Representações Sociais: Investigações em psicologia social. Petrópolis, RJ: Vozes.

Moscovici, S. (2012). A psicanálise, sua imagem e seu público. Petrópolis, RJ: Vozes.

Mufaddel, A., \& Abdelgani, A. E. (2014). Psychiatric comorbidity in patients with psoriasis, vitiligo, acne, eczema, and group of patients with miscellaneous dermatological diagnoses. Open Journal of Psychiatry, 4, 168-175. doi: 10.4236/ ojpsych.2014.43022

Müller, M. C. (2005). Psicossomática: Uma visão simbólica do vitiligo. São Paulo, SP: Vetor.

Müller,M.C., \&Ramos, D.(2004). Psicodermatologia: Uma interface entre psicologia e dermatologia. Psicologia: Ciência e Profissão, 24(3), 7681. Retrieved from http://pepsic.bvsalud.org/ scielo.php?script $=$ sci_arttext $\&$ pid $=\mathrm{S} 1414$ 98932004000300010\&lng=pt\&tlng=pt

National Health Council. (2012). Resolução 466/2012. Brasília, DF: Author.

Nóbrega, S. M. (2001). Sobre a teoria das representações sociais. In A. Moreira, Representações sociais: Teoria e prática (pp. 55-87). João Pessoa, PB: Editora Universitária.

Noh, S. N., Kim, M., Park, C. O., Hann, S. K., \& Oh, S. H. (2013). Comparison of the psychological impacts of asymptomatic and symptomatic cutaneous diseases: Vitiligo and atopic dermatitis. Annals of Dermatology, 25(4), 454 461. doi: 10.5021/ad.2013.25.4.454

Njoo, M. D., \& Westerhof, W. (1997). Vitiligo. Nederlands Tijdschrift voor Geneeskunde, 141(16), 759-764. Retrieved from https://www. ncbi.nlm.nih.gov/pubmed/9213796

Oliveira, D. C. (2000). Representações sociais e saúde pública: A subjetividade como partícipe do cotidiano em saúde. Revista de Ciências Humanas, (2), 47-65.

Ongenae, K., Dierckxsens, L., Brochez, L., van Geel, N., \& Naeyaert, J. M. (2005). Quality of life and stigmatization profile in a cohort of vitiligo patients and effects of the use of camouflage. Dermatology, 210, 279-285. doi: $10.1159 / 000084751$

Pahwa, P., Mehta, M., Khaitan, B. K., Sharma, V. K., \& Ramam, M. (2013). The psychosocial impact of vitiligo in Indian patients. Indian Journal of Dermatology, Venereology and Leprology, 79, 679-685. doi: 10.4103/0378-6323.116737

Panda, A. K. (2005). The medico historical perspective of vitiligo. Bulletin of the Indian Institute of History of Medicine, 25, 41-46. Retrieved from https://www.ncbi.nlm.nih.gov/ pubmed/17333661

Pettigrew, T. F., \& Meertens, R. W. (1995). Subtle and blatant prejudice in Western Europe. European Journal of Social Psychology, 25, 203-226.

Prasad, P. V., \& Bhatnagar, V. K. (2003). Medicohistorical study of "Kilasa" (vitiligo/leucoderma) a common skin disorder. Bulletin of the Indian Institute of History of Medicine, 33, 113-127. Retrieved from https://www.ncbi.nlm.nih.gov/ pubmed/17154114

Rosa, E., \& Natali, M. (2009). Vitiligo: Um problema que não pode passar em branco. Saúde e Pesquisa, 2, 119-126. Retrieved from http://periodicos.unicesumar.edu.br/index.php/ saudpesq/article/view/910/732

Sá, C. P. D. (2002). Núcleo central das representações sociais. Petrópolis, RJ: Vozes.

Sant'Anna, P. A., Giovanetti, R. M., Castanho, A. G., Bazhuni, N. F. N., \& La Selva, V. A. (2003). A expressão de conflitos psíquicos em afecções dermatológicas: Um estudo de caso de uma paciente com vitiligo atendida com o jogo de areia. Psicologia: Teoria $e$ Prática, 5(1), 81-96. Retrieved from http:// pepsic.bvsalud.org/scielo.php? script $=$ sci arttext\&pid=S1516-36872003000100007

Sarham, D., Mohammed, G. F. A, Gomaa, A. H. A., \& Eyada, M. M. K. (2016). Female genital dialogues: Female genital self-image, sexual dysfunction, and quality of life in patients with vitiligo with and without genital affection. Journal of Sex \& Marital Therapy, 42(3), 267276. doi: 10.1080/0092623X.2015.101067 
Shimuzu, H. E., Silva, J. R., Moura, L. M., Bermúdez, X. P., \& Odeh, M. M. (2015). A estrutura das representações sociais sobre saúde e doença entre membros de movimentos sociais. Ciência \& Saúde Coletiva, 20(9), 2899-910. doi: 10.1590/1413-81232015209.20592014

Silva, A., Castoldi, L., \& Kijner, L. C. (2011). A pele expressando o afeto: Uma intervenção grupal com pacientes portadores de psicodermatoses. Contextos Clínicos, 4(1), 53-63. doi: 10.4013/ ctc. 2011.41 .06

Steiner, D., Bedin, V., Moraes, M. B., Villas, R. T., \& Steiner, T. (2004). Vitiligo. Anais Brasileiros de Dermatologia, 79(3), 335-351. doi: 10.1590/ S0365-05962004000300010

Szabo, I., \& Brandão, E. R. (2016). "Mata de tristeza!": Representações sociais de pessoas com vitiligo atendidas na Farmácia Universitária da Universidade Federal do Rio de Janeiro, Brasil. Interface - Comunicação, Saúde, Educação, 20(59), 953-965. doi: 10.1590/180757622015.0596

Vala, J. (2000). Representações sociais e psicologia social do conhecimento cotidiano. In J. Vala \& M. B. Monteiro (Eds.), Psicologia social (pp. 457-502). Lisboa: Fundação Calouste Gulbenkian.

Received: $02 / 04 / 2018$

$1^{\text {st }}$ revision: 09/09/2018

Accepted: 13/09/2018

(c) BY (C) The Author(s), 2018. Open Access. This article is distributed under the terms of the Creative Commons Attribution 4.0 International License (http://creativecommons.org/licenses/by/4.0/), which permits unrestricted use, distribution, and reproduction in any medium, provided you give appropriate credit to the original author(s) and the source, provide a link to the Creative Commons license, and indicate if changes were made. 